Article

\title{
The Theorized Relationship between Organizational (Non)Compliance with the United Nations Guiding Principles on Human Rights and Desired Employee Workplace Outcomes
}

\author{
Magda B. L. Donia ${ }^{1, *(\mathbb{D}}$, Salvador Herencia Carrasco ${ }^{2}$, Sara Seck ${ }^{3}\left(\mathbb{D}\right.$, Robert McCorquodale ${ }^{4}(\mathbb{D}$ \\ and Sigalit Ronen ${ }^{5}$ \\ 1 Telfer School of Management, University of Ottawa, Ottawa, ON K1N 6N5, Canada \\ 2 Faculty of Law, University of Ottawa, Ottawa, ON K1N 6N5, Canada; shere045@uottawa.ca \\ 3 Schulich School of Law, Dalhousie University, Halifax, NS B3H 4R2, Canada; sara.seck@dal.ca \\ 4 School of Law, University of Nottingham, Nottingham NG7 2RD, UK; \\ robert.mccorquodale@nottingham.ac.uk \\ 5 David Nazarian College of Business and Economics, California State University, Northridge, CA 91330, USA; \\ sigalit.ronen@csun.edu \\ * Correspondence: donia@telfer.uottawa.ca
}

Received: 5 February 2020; Accepted: 4 March 2020; Published: 10 March 2020

\begin{abstract}
Despite the presence of guiding legislation such as the United Nations Guiding Principles, respect for human rights is subject to the conscience of organizational actors. Given that some transnational corporations are more powerful than nation states, they play an important role in the economies in which they operate, often with far-reaching impact on the labor conditions and human rights protections within these countries. In the current global context, respect for human rights may be undermined when organizational decision-makers are tempted to ignore unethical practices due to considerations such as competition and short-term financial incentives. We propose that the higher standards to which younger generations increasingly hold corporations provide a compelling and "business case" incentive for the protection of human rights of external stakeholders by organizational decision-makers. Drawing on related research on corporate social responsibility and on projections regarding demographical changes in the workplace worldwide, we make the case for a bottom-line advantage to respecting human rights in attracting and retaining top talent in work organizations. We conclude by highlighting the theoretical and practical implications of our theorizing.
\end{abstract}

Keywords: human rights; United Nations Guiding Principles; employee attitudes; employee behaviors; corporate social responsibility

\section{Introduction}

Transnational corporations have economic power rivaling that of many countries [1] and play an important role in the economies in which they operate, often with far-reaching impacts on human rights protections. In this context, corporate enactment and enforcement of human rights has been referred to as the "moral face of globalization" [2], given that in the current global context, even in the presence of guiding legislation, respect for human rights by corporations is often left to the conscience of organizational decision-makers. One well known example is that of extractive companies, which among other industry sectors, have been implicated in a wide range of human rights violating behaviors [3-5].

The United Nations Guiding Principles on Business and Human Rights (UNGPs) were endorsed in 2011 by the Human Rights Council, with the goal of providing a compass to guide organizations 
toward the respect of human rights in their business operations, as stated in Principle 11 of the UNGPs. The business responsibility to respect human rights (as specified in the second pillar of the UNGPs) reflects social expectations going beyond what is mandated by law. For example, Principle 13 requires businesses to avoid causing or contributing to create adverse impacts on human rights in their activities. The broad language of this principle infers a duty of care throughout their entire operations, which could go beyond what is established in law. As detailed in Table 1, the implementation of the business responsibility to respect human rights provides an opportunity for businesses to engage in responsible business conduct that is visible to their employees.

Table 1. United Nations Guiding Principles on Business and Human Rights' (UNGPs) Pillar 2 Guiding Principles and observable organizational actions.

\begin{tabular}{cc}
\hline Pillar 2 Guiding Principles & Observable Examples to Employees \\
\hline $\begin{array}{c}\text { Principle 11. Business enterprises should respect human } \\
\text { rights. This means that they should avoid infringing on the } \\
\text { human rights of others and should address adverse human } \\
\text { rights impacts with which they are involved. }\end{array}$ & $\begin{array}{c}\text { Having an open door policy to encourage } \\
\text { employees to report observed abuses. An } \\
\text { organization operating in a host country } \\
\text { should also engage with local communities to } \\
\text { proactively get feedback from their practices. }\end{array}$ \\
\hline $\begin{array}{c}\text { Principle 12. The responsibility of business enterprises to } \\
\text { respect human rights refers to internationally recognized } \\
\text { human rights - understood, at a minimum, as those } \\
\text { expressed in the International Bill of Human Rights and the } \\
\text { principles concerning fundamental rights set out in the } \\
\text { International Labour Organization's Declaration on } \\
\text { Fundamental Principles and Rights at Work. }\end{array}$ & $\begin{array}{c}\text { An organization that is committed to } \\
\text { respecting human rights is likely to have a } \\
\text { clear statement on what this means, and } \\
\text { specifically on the nature of these rights } \\
\text { eliminating any ambiguity or relativity in } \\
\text { interpreting the impacts of } \\
\text { organizational actions. }\end{array}$ \\
\hline
\end{tabular}

Principle 13. The responsibility to respect human rights requires that business enterprises: (a) avoid causing or contributing to adverse human rights impacts through their own activities, and address such impacts when they occur; (b) seek to prevent or mitigate adverse human rights impacts that are directly linked to their operations, products, or services by their business relationships, even if they have not contributed to those impacts.

14. The responsibility of business enterprises to respect human rights applies to all enterprises regardless of their size, sector, operational context, ownership, and structure. Nevertheless, the scale and complexity of the means through which enterprises meet that responsibility may vary according to these factors and with the severity of the enterprise's adverse human rights impacts.

15. In order to meet their responsibility to respect human rights, business enterprises should have in place policies and processes appropriate to their size and circumstances, including:
Regardless of the area and size of the company, businesses should attempt to have a human rights compliance plan in practice that can identify, prevent, mitigate, and compensate possible abuses.

\footnotetext{
(a) a policy commitment to meet their responsibility to

respect human rights; (b) a human rights due diligence process to identify, prevent, mitigate, and account for how they address their impacts on human rights; (c) processes to enable the remediation of any adverse human rights impacts they cause or to which they contribute.
}

Employees should be allowed to participate in the drafting and adoption of due diligence processes and other policies to assure that their operations do not infringe on human rights. 
Table 1. Cont.

\begin{tabular}{|c|c|}
\hline Pillar 2 Guiding Principles & Observable Examples to Employees \\
\hline $\begin{array}{l}\text { 16. As the basis for embedding their responsibility to respect } \\
\text { human rights, business enterprises should express their } \\
\text { commitment to meet this responsibility through a statement } \\
\text { of policy that: (a) is approved at the most senior level of the } \\
\text { business enterprise; (b) is informed by relevant internal } \\
\text { and/or external expertise; (c) stipulates the enterprise's } \\
\text { human rights expectations of personnel, business partners, } \\
\text { and other parties directly linked to its operations, products, } \\
\text { or services; (d) is publicly available and communicated } \\
\text { internally and externally to all personnel, business partners, } \\
\text { and other relevant parties; (e) is reflected in operational } \\
\text { policies and procedures necessary to embed it throughout } \\
\text { the business enterprise. }\end{array}$ & $\begin{array}{c}\text { True commitment to respecting human rights } \\
\text { exists when it permeates the entire } \\
\text { organization. It starts at the top with } \\
\text { leadership and top management, and by a } \\
\text { system of policies aimed at generating a } \\
\text { culture of respect, becomes present in the } \\
\text { entire organization. In this way, organizations } \\
\text { do not just pay lip service to respecting } \\
\text { human rights, it reflects a core value of } \\
\text { the organization. }\end{array}$ \\
\hline
\end{tabular}

17. In order to identify, prevent, mitigate, and account for how they address their adverse human rights impacts, business enterprises should carry out human rights due diligence. The process should include assessing actual and potential human rights impacts, integrating and acting upon the findings, tracking responses, and communicating how impacts are addressed. Human rights due diligence: (a) should cover adverse human rights impacts that the business enterprise may cause or contribute to through its own activities, or which may be directly linked to its operations, products, or services by its business relationships; (b) will vary in complexity with the size of the business enterprise, the risk of severe human rights impacts, and the nature and context of its operations; (c) should be ongoing, recognizing that the human rights risks may change over time as the business enterprise's operations and operating context evolve.

Human rights due diligence policies are one of the most important tools that businesses should adopt. The UNGPs establish a series of guidelines that organizations truly committed

to respecting human rights can adopt to include employees in the drafting, implementing, and reviewing of the policy.

18. In order to gauge human rights risks, business enterprises should identify and assess any actual or potential adverse human rights impacts with which they may be involved, either through their own activities or as a result of their business relationships. This process should: (a) draw on internal and/or independent external human rights expertise; (b) involve meaningful consultation with potentially affected groups and other relevant stakeholders, as appropriate to the size of the business enterprise and the nature and context of the operation.

19. In order to prevent and mitigate adverse human rights impacts, business enterprises should integrate the findings from their impact assessments across relevant internal functions and processes and take appropriate action. (a) Effective integration requires that: (i) responsibility for addressing such impacts is assigned to the appropriate level and function within the business enterprise; (ii) internal decision-making, budget allocations, and oversight processes enable effective responses to such impacts. (b) Appropriate action will vary according to: (i) whether the business enterprise causes or contributes to an adverse impact, or whether it is involved solely because the impact is directly linked to its operations, products, or services by a business relationship; (ii) the extent of its leverage in addressing the

A true commitment to protecting human rights would be apparent to employees by the many systems in place to ensure that in addition to an organization's own operations, all of the partners in its value chain (e.g., suppliers) abide by ethical business practices.

This commitment would be even more apparent to employees when their organization operates in an environment with lax local laws, whereby ethical practices are a true reflection of the organization's values

(rather than driven by local laws or external pressure). adverse impact. 
Table 1. Cont.

\begin{tabular}{|c|c|}
\hline Pillar 2 Guiding Principles & Observable Examples to Employees \\
\hline $\begin{array}{l}\text { 20. In order to verify whether adverse human rights impacts } \\
\text { are being addressed, business enterprises should track the } \\
\text { effectiveness of their response. Tracking should: (a) be based } \\
\text { on appropriate qualitative and quantitative indicators; (b) } \\
\text { draw on feedback from both internal and external sources, } \\
\text { including affected stakeholders. }\end{array}$ & $\begin{array}{l}\text { Employees working on the monitoring of due } \\
\text { diligence and other human rights policies } \\
\text { should be able to collect data to assess and } \\
\text { communicate the impact of such policies. }\end{array}$ \\
\hline
\end{tabular}

21. In order to account for how they address their human rights impacts, business enterprises should be prepared to communicate this externally, particularly when concerns are raised by or on behalf of affected stakeholders. Business enterprises whose operations or operating contexts pose risks of severe human rights impacts should report formally on how they address them. In all instances, communications should: (a) be of a form and frequency that reflect an enterprise's human rights impacts and that are accessible to its intended audiences; (b) provide information that is sufficient to evaluate the adequacy of an enterprise's response to the particular human rights impact involved; (c) in turn, not pose risks to affected stakeholders, personnel, or to legitimate requirements of commercial confidentiality.

22. Where business enterprises identify that they have caused or contributed to adverse impacts, they should provide for, or cooperate in, their remediation through legitimate processes.

Employees of organizations committed to protecting human rights will not be instructed to keep quiet about human rights concerns of their operations. Instead they will be instructed on how to share open and honest information about a situation, as well as the steps being taken to address and remedy concerns.

\footnotetext{
23. In all contexts, business enterprises should: (a) comply with all applicable laws and respect internationally recognized human rights, wherever they operate; (b) seek ways to honor the principles of internationally recognized human rights when faced with conflicting requirements; (c) treat the risk of causing or contributing to gross human rights abuses as a legal compliance issue wherever they operate.

24. Where it is necessary to prioritize actions to address actual and potential adverse human rights impacts, business enterprises should first seek to prevent and mitigate those that are most severe or where delayed response would make them irremediable.

Employees will observe their organization as a leader, or at least engaging in best practices, relative to competitors in the same industry.

The commitment to prevent and mitigate further adverse impacts will be apparent to employees through the investment of necessary resources to truly have an impact and reverse a negative situation.
}

Given that public opinion is an important motivator for good behavior and a detractor of bad behavior, the impressions of organizational internal stakeholders (i.e., employees) may provide a strong incentive for organizations to uphold practices consistent with the UNGPs within their operations. Research on corporate social responsibility (CSR) has found that both the extent of organizational involvement (i.e., how much) and employees' attributions of organizations' motives (i.e., whether organizations are selflessly or self-servingly engaging in CSR) are significantly correlated with employees' attitudes and performance at work [6,7]. For example, research has found that greater involvement in CSR initiatives leads to greater employee commitment [8] and trust in the organization [9]. Furthermore, also noteworthy is the finding that employees respond more positively when they believe their organization engages in CSR for selfless reasons [10].

As such, research on CSR may provide valuable lessons for advancing research on the protection of human rights by corporations, with the UNGPs as a governing instrument. First, it is important to clarify that we adopt Aguinis' [11] conceptualization of CSR as "context-specific organizational actions and policies that take into account stakeholders' expectations and the triple bottom line of economic, social, and environmental performance". Inherent in this definition is the discretionary nature of these organizational behaviors. This therefore fundamentally differs from the concept of business 
responsibilities for human rights (BHR) in the UNGPs, which essentially points to the responsibility of the organization. In an attempt to steer away from confusion, we therefore refer to CSR when intending to capture research on the impact of externally directed organizational practices that are discretionary, and to the UNGPs and the protection of human rights to capture organizational practices toward upholding and protecting human life and dignity. It is also important to point out that while for the purposes of our theorizing we focus our discussion on CSR, other related constructs (such as corporate philanthropy and corporate social performance [12]) have been proposed and when empirically tested, found to impact employee workplace outcomes. While these constructs may vary in their theorized target (CSR vs. corporate sustainability) or intensity (CSR vs. corporate philanthropy), they are generally related and capture more of a "nice to have" element of organizations' responsible behavior while the duty to protect human rights speaks to a fundamental and "must have" behavior.

Given this distinction and the fundamental nature of human rights, we expect more positive employee attitudinal and behavioral workplace responses to instances of organizational actions aimed at respecting human rights in accordance with principles laid out in the UNGPs. For example, in the context of mining, even employees located in the home country and distant from the ground operations in a host country, are expected to be aware of any adverse human rights impacts of their organizations' operations as well as of the measures (if any) the organization takes at remediation (captured in Principle 21 of the UNGPs). As such, through daily life in the organization, employees are assumed to become aware through human rights due diligence activities of the company that should be conducted for compliance with the UNGPs.

In line with increasing consensus that the key to sustainably addressing societal problems is securing the collaboration of multiple actors, we argue a business case for organizations to exert stewardship in the protection of human rights in compliance with the UNGPs. In so doing, we suggest that employees' beliefs regarding the extent to which their organizations' practices respect or violate the human rights of external stakeholders (i.e., non-organizational members) may affect not only how they perceive their organization, but also workplace attitudinal and behavioral outcomes, such as commitment to the organization and individual performance. The implications of this are far reaching, as it means that employees of a home office located in a developed country may experience negative attitudinal and behavioral outcomes at work from perceived human rights violations of their company operating in a developing country. This is especially relevant in the backdrop of important generational changes taking place in the workplace.

The rapidly changing face of the global workforce influences our theorizing. Projected to make up $75 \%$ of the global population by 2025 [13], millennials are "bringing about important changes in work culture through their charitable interests and engagement" [14]. A growing societal expectation of corporations' responsibility to respect human rights is also increasingly evident in the growth of environmental, social, and governance (ESG) investing. Essentially, more people are aligning their values and their money as evidenced by the rise in the number of investment funds using ESG factors from less than 50 in 2000 to almost 1100 in 2016, with all major asset managers now offering ESG products [15]. Not surprisingly, given that younger generations increasingly attempt to integrate their money and values, " $76 \%$ of high net-worth millennial investors have reviewed their assets for ESG impact" and overall, "millennial investors are twice as likely as others to invest in companies that incorporate ESG practices" [15].

We therefore propose a bottom line advantage to respecting human rights in attracting and retaining top talent as the representation of younger generations with strong moral values in the workforce grows. This is in line with research on the related construct of CSR, which has found that the more employees observe their organizations engaging in CSR, the more they experience positive workplace attitudes (e.g., commitment [16]) and the better they perform [17]. Drawing on these findings from CSR research, we argue that employees will also respond positively to their organizations' compliance with human rights practices, especially when they perceive it to be substantively motivated (i.e., genuinely motivated, as opposed to greenwashing). We begin by reviewing the literature on 
relevant attempts to encourage organizations to protect human rights. We then develop propositions drawing on findings in the CSR literature and argue that positive employee outcomes can be viewed as a novel incentive for organizations to protect human rights. We conclude by highlighting the key theoretical and practical contributions of our theorizing.

\section{Review of the Literature on Attempts to Encourage Organizational Protection of Human Rights}

The UNGPs provide an operational framework for business entities' activities to ensure respect for human rights (UN; [18]). The UNGPs comprise three pillars: (1) a state obligation to protect human rights; (2) the corporate responsibility to respect human rights; and (3) access to judicial and non-judicial remedies. Our theorizing focuses on the second pillar, and as explained below, on the effects that compliance/non-compliance with the UNGPs has on employees, as observers of the outcomes of their organizations' actions toward external stakeholders.

The negative consequences of corporate actions on human rights around the world have led to the introduction of international regulations and greater direct legal obligations on corporations [19]. Since their adoption, the UNGPs have been equally lauded for clarifying the legal obligations of states and the human rights responsibility of business entities, as well as criticized for their failure to deliver or call for binding legal obligations for these organizations [20]. The business responsibility to respect rights of the UNGPs has been embedded in international CSR and responsible business conduct guidance tools, including those of the OECD, which are promoted by governments to businesses operating internationally [21,22]. The normative weight and thus legal relevance of the business responsibility to respect rights in Pillar 2 is expected to increase over time [23]. Regardless of the strengths and shortcomings of the UNGPs, the current reality is one where many companies continue to create adverse impacts on human rights, and there remains a governance gap [24]. With two exceptions to date (France's Duty of Vigilance Law 2017 and the Netherlands Child Labour Due Diligence Act 2019), states have not developed domestic laws to regulate the transnational conduct of business entities domiciled within their jurisdiction, although there are signs that some courts may be increasingly open to transnational corporate accountability litigation invoking human rights [25].

While the UN Human Rights Council is currently holding a process to negotiate a legally binding instrument to regulate the activities of transnational companies and other business enterprises, as well as an optional protocol that will oblige states to adopt a national implementation mechanism to monitor the fulfillment of such instrument (i.e., "Revised Draft", released in July 2019), it focuses on Pillars 1 and 3, thus failing to address directly issues of corporate responsibilities related to human rights (i.e., Pillar 2). This is significant as the lack of binding regulation makes a focus on the responsibility of business operations to avoid infringing on human rights and to address the potential human rights impacts of their operations. For example, McCorquodale, Smit, Neely, and Brooks [26] (p. 206) found that " $77.14 \%$ of companies using dedicated human rights due diligence (HRDD) identify adverse impacts, whereas $80.77 \%$ of companies using non-specific HRDD did not identify adverse impacts".

\section{A Micro-Level Perspective}

A micro-level research focus on the related construct of CSR gained attention and momentum in the early 2000s [27]. That research has developed an important and growing body of work demonstrating that organizational actions toward external stakeholders have consequences for their internal stakeholders (i.e., employees). This is significant because it suggests that organizational members do not just care about their daily work and how their relationship to the organization affects them, but are concerned with, and are impacted by, their organizations' actions toward the external environment.

Below we begin by discussing some of the theoretical mechanisms that have been drawn on to explain the link between organizational CSR initiatives and employees' ensuing attitudes and behaviors at work. We then review findings of important employee workplace attitudinal and behavioral workplace outcomes in that literature to argue at least similar findings in the relationship 
between organizational compliance with the UNGPs and employees' workplace outcomes. As CSR is by definition more discretionary (i.e., recycling, giving back to the community), we expect that employees' workplace attitudes and behaviors will be more strongly impacted by their organizations' compliance with the UNGPs.

\section{Deriving Meaning from Organizational Actions Directed toward External Stakeholders}

Meaningfulness is considered a fundamental human need [28] and thus, given the central role of work in most peoples' lives, it plays an important role in individuals' self-worth. In a recent review of findings of micro-level CSR research, Aguinis and Glavas [29] suggest that organizational CSR activities impact employee outcomes by affecting the meaningfulness employees derive through work. Research by Donia et al. [10] found that organizational actions directed toward external stakeholders are important because they provide information to employees about the general character of the organization. That research found that employees' perceived fit with their organization (i.e., the alignment of their own values and those of their organization) mediated the relationship between their CSR attributions and their ensuing workplace outcomes.

While the impact of organizational actions directed toward external stakeholders has been argued to be dependent on important individual characteristics, such as the extent to which employees care about fair treatment to external stakeholders and employees' own moral development $[6,29]$, we expect this to matter for two reasons. First, individuals seem increasingly to care about their organizations' role in society and their standing as good citizens. For example, millennials, who are currently the largest generation in the US workforce [30], attach more meaning to work and expect more from organizations (i.e., private companies). Additionally, according to one report, $78 \%$ of millennials in the USA make charitable donations on their own (i.e., outside of those that are organization assisted [31]). Unlike previous generations, this group, who will represent $50 \%$ of the global workforce by 2020 [32], also appears to place greater value on meaningful work than on their financial compensation, while holding organizations to higher standards. One report by Deloitte [33] (p. 9) found that $54 \%$ of respondents negatively described organizations as appearing to have "no ambition beyond making money".

Secondly, more self-interested employees are also expected to respond more favorably when observing their organizations' positive interactions with external stakeholders. Third-party perceptions of fairness theory [34] suggest that individuals reciprocate to the enactor of (mis)treatment of a third party. When a third party is viewed as being treated unfairly, the authors suggest that an observer is in turn motivated to restore justice (either behaviorally or cognitively). This is because they can draw inferences about their own future treatment on the basis of how they observe others being treated [35]. Similar to micro-level CSR research that assesses employee responses to active behaviors intended to do good (e.g., "We encourage partnerships with local businesses and schools" [36] (p. 292)), and abstaining from actions that would cause harm (e.g., "My organization takes great care that our work does not hurt the environment" [37] (p. 192)), we theorize that employees respond favorably to both positive actions, and the withholding of negative actions, directed at respecting human rights in daily operations, and especially in industries where human rights violations may be more commonplace (e.g., mining).

\section{Lessons from CSR Research: The Effect of "How Much" and "Why" of CSR on Employee Outcomes}

Research on CSR has found that both the extent of organizational involvement (i.e., how much), and employees' attributions of organizations' motives (i.e., whether organizations are selflessly or self-servingly engaging in CSR), are significantly correlated with employees' attitudes and performance at work (e.g., $[7,10])$. Moreover, also noteworthy is the finding that employees respond more positively when they believe their organization engages in CSR for selfless reasons [6,10].

Research on micro-CSR has consistently identified positive employee workplace outcomes as resulting from these initiatives. Potential job applicants report being more attracted to organizations 
with greater CSR involvement [38,39]. Once in the organization, research has consistently found organizational CSR involvement to be positively associated with valued employee workplace attitudes, such as commitment to the organization (e.g., [37,40]), pride in the organization (e.g., [41]), and trust in the organization (e.g., [9]), and negatively associated with undesirable attitudes, such as organizational cynicism (e.g., [42]) and turnover intentions (e.g., [9]).

Equally important has been the finding that organizational involvement in CSR has positive implications for employee workplace behaviors. For example, Jones (2010) found that employees who were allowed to engage in a volunteering program of their choice during paid company time engaged in more organizational citizenship behaviors (OCBs; valued extra-role performance). In fact, there is even research evidence that perceived CSR involvement is a stronger predictor of employee job performance than perceived market and financial performance [43].

In light of these findings, and given that public opinion is an important motivator for good behavior and detractor of bad behavior [44], the impressions of organizational internal stakeholders (i.e., employees) may provide an even stronger incentive for organizations to comply with the UNGPs, and particularly Pillar 2. One important assumption underlying our theorizing is that, in the present day, employees believe that protection of human rights and the environment in daily operations is a social expectation [19] and a moral imperative of organizations [33]. The attraction and retention of productive, motivated, and satisfied employees may therefore provide a compelling reason for organizational compliance with human rights obligations through employees' organizational work outcomes. This research is also consistent with Principle 20 of the UNGPs, which calls on organizations to track the effectiveness of measures adopted to address human rights concerns. In order to achieve this, it specifically calls on organizations to include internal feedback in their assessments.

Research considering the related construct of CSR by McShane and Cunningham [45] found that "employees made authenticity judgments about their organizations' CSR initiatives and that these judgments in turn affected how employees responded to these initiatives" [6] (p. 104). Similar research has found that the more employees observe their organizations engaging in CSR, the more they experience positive workplace attitudes (e.g., commitment [16]) and behaviors (e.g., employee performance [17]). If observing organizational engagement in CSR appears to increase employee wellbeing and performance at work, it is possible that employees would also respond positively to their organizations' compliance with human rights practices, as shown in Figure 1. In fact, we expect more positive employee responses to judgements of their organizations' respect for human rights for two reasons. First, while CSR can include an almost limitless range of observable behaviors (e.g., recycling, participating in a food drive to benefit a women's shelter, contributing to a project to plant trees), those relating to human rights are more limited and focused on the protection of human dignity (e.g., child labor, compulsory labor [46]). Because of this, the latter are more observable and carry greater moral weight. Second, and related to the previous, is that issues of human rights' protection/violations may be particularly salient and more prevalent for organizations operating within certain contexts (such as mining). In other words, the organizations for whom the protection of human rights is most important and relevant (i.e., multinational corporations with a large international presence) are also the ones whose actions are most visible to their employees and thus expected to be more notable than CSR practices.

Proposition 1: Organizational compliance with human rights' guidelines will be positively associated with valued employee attitudes (e.g., organizational commitment) and behaviors (e.g., performance).

Taking into account the research that has been done with CSR, we believe that company policies implementing the UNGPs, particularly the second pillar, will have a positive effect on organizational commitment and performance by employees.

Identification with the organization is one potential mechanism by which organizational compliance with the UNGPs affects employees' workplace outcomes. One plausible explanation is 
that employees—and especially millennials who hold corporations to higher standards-tend to feel better about themselves when they work in organizations that uphold values that are congruent with their self-image. In turn, they experience a greater fit with the organization as this meets their "desire ... to be part of a high-performance group and to bask in its reflected glory, even if this glory is not a direct result of their own actions" [43] (p. 975). This is line with the finding that 58\% of employees surveyed reported a willingness to accept a $15 \%$ cut in pay in order to work for an organization with values similar to their own [32].

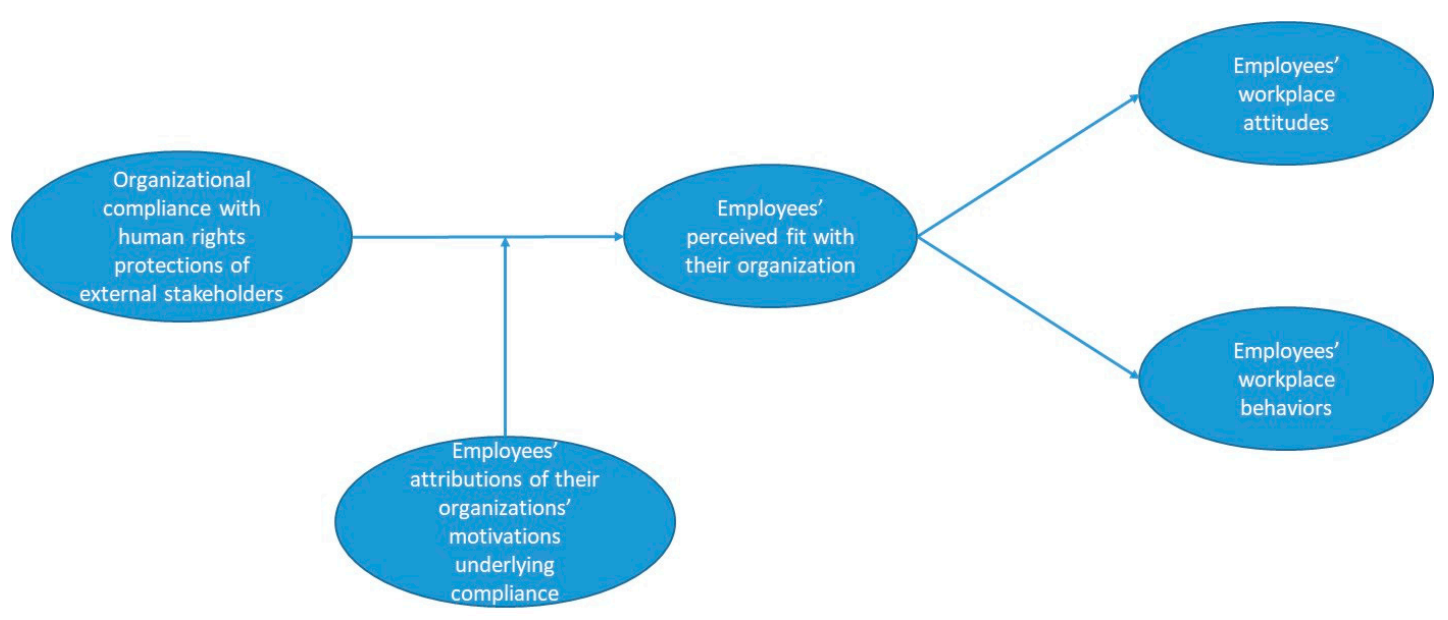

Figure 1. Theoretical model.

Proposition 2: The positive relationships between organizational compliance with human rights' guidelines and valued employee attitudes (e.g., organizational commitment) and behaviors (e.g., performance) will be mediated by perceived fit with the organization.

Research on CSR has found that it is not enough that organizations engage in discretionary actions, but that in addition to merely engaging in such actions they do so for the right reasons. A recent study found that employees appear to respond positively (e.g., positive attitudes at work) when they interpret their organizations' CSR initiatives as substantive (i.e., undertaken for selfless reasons, with a real focus on contributing to local communities or protecting the environment [10]). In contrast, when employees perceived the organization as engaging in symbolic CSR (i.e., self-serving, for reputation enhancement), not only were these positive effects attenuated, but a negative relationship between CSR and positive work-related attitudes and behaviors was observed. These findings support the fact that when employees view organizational CSR practices as merely advertising and public relation efforts, they are likely to view them as symbolic, and react negatively [10]. Abramovitch [47] pointed to the backlash Whole Foods faced from its employees when it discarded large quantities of food deemed unsellable, while including in its mission the value of giving to the community, reflecting judgements that the company could have and should have done more to the cause of feeding the hungry [6].

Because of the broader nature of human rights protections and the specific clarification of human rights, employees are expected to respond more favorably to their organizations' compliance with protecting human rights through compliance with the UNGPs when they view the organization as genuinely committed to protecting human rights. Given that "people care less about what others do than about why they do it" [48] (p. 21), the positive attitudinal and behavioral outcomes of employees should be more favorable when they believe their organizations comply with the UNGPs for substantive (vs. symbolic) reasons.

Proposition 3: The positive relationships between organizational compliance with human rights' guidelines and valued employee attitudes (e.g., organizational commitment) and behaviors (e.g., performance) will be moderated 
by employee attributions of compliance. That is, it will be stronger when attributed as substantive, and weaker when attributed as symbolic.

\section{Discussion}

We propose a different lens from which to approach organizational compliance with the UNGPs. The stronger commitments made by organizations (e.g., greater transparency, accountability, and measures to adapt or redress negative impacts of operations on human rights) are expected to benefit their internal operations in the form of valued employee workplace outcomes. Given the many challenges associated with universally endorsed and implemented legislation to guide organizational compliance, we suggest an incentive-based approach by demonstrating the advantages of compliance (and challenges of non-compliance). This incentive-based approach will benefit organizations and society alike.

It is also important to note that this organizational compliance model with the UNGPs attempts to fulfill the organizational elements from the principles stated in the second pillar. For example, in the development of due diligence and other internal policies related to human rights, the UNGPs clearly call on business to use internal expertise from the business to adopt internal policies (Principle 16) as well as to assess their impacts (Principle 18). This is fundamental for the success of any UNGPs-based policy as the employees are the ones responsible for their incorporation within company procedures (Principle 19). If employees perceive that their expertise is being used to implement meaningful human rights policies, we believe that this could have positive impacts for all stakeholders.

\subsection{Implications for Theory}

A focus on human rights more broadly, and organizational compliance with the UNGPs in particular, offers two novel and important avenues for research in the study of the impact of organizational actions on employee outcomes. First, while micro-level research on outcomes of CSR has made significant advances to our understanding of how organizational actions directed toward external stakeholders can impact internal (and often unrelated and unaffected) stakeholders, the focus of organizational activities has been on less impactful actions. For example, a close look at the measures used to assess CSR demonstrates these to be more neutral than human rights considerations. For example, "Quality of products, services, or programs", "Ability to retain essential employees" [43], "We strive to lower our operating costs" [48], and "ATG Company cares about the environment" [43]. As such, it is possible that employee responses to organizational compliance with the UNGPs will be much stronger in comparison to responses to organizational engagement in CSR initiatives (e.g., while a CSR approach by a shoe company would be to give old shoes to poor communities, a human rights approach would be to provide living wages to those who are making the shoes).

Second and relatedly, a focus on human rights will allow for more fine-grained empirical research that is context specific, thus providing more actionable findings to relevant stakeholders. For example, research that focuses on activities of organizations in extractive industries, or multinationals operating in developing countries, may uncover stronger effects on employees than those operating in the service industry in North America. An important and highly visible example is that of Canadian mining organizations operating in Latin America. Following a country visit to Canada, the United Nations Working Group on Business and Human Rights highlighted grave concerns, including allegations of "30 targeted deaths and 709 cases of "criminalization" associated with the operations of 28 Canadian organizations during the period from 2000 to 2015" [49] (p. 4). It is expected that employees of such organizations would report less positive workplace attitudes and behaviors than counterparts in organizations in the same industry with a better human rights track record.

\subsection{Implications for Practice}

Including the perspective of organizational members (i.e., employees) is expected to provide a compelling motivation for organizations to do the right thing. While there may often be financial 
considerations involved in failing to comply with the UNGPs, we believe that employee attitudinal responses, such as commitment to and pride in the organization, as well as their job performance, will convince organizations that compliance with the UNGPs makes moral and financial sense.

\section{Conclusions}

In this paper, we provided a theoretical argument for the empirical study of the impact of organizational compliance with the UNGPs and employee workplace outcomes. Given that businesses should respect human rights, an understanding of ensuing employee workplace attitudinal and behavioral outcomes may provide a compelling incentive for organizational compliance, one that makes moral as well as financial sense.

Author Contributions: This conceptual paper is made possible thanks to the complementary nature of each author's expertise and reflects an equal and synergistic collaboration. Conceptualization, M.B.L.D.; Writing-Original Draft Preparation, M.B.L.D., S.H.C., S.S., R.M., and S.R.; Writing-Review \& Editing, M.B.L.D., S.H.C., S.S., R.M., and S.R.; Supervision, M.B.L.D.; Project Administration, M.B.L.D.; Funding Acquisition, M.B.L.D., S.H.C., S.S., R.M., and S.R. All authors have read and agreed to the published version of the manuscript.

Funding: This research was funded by the Social Sciences and Humanities Research Council of Canada, grant number 430-2019-00849.

Acknowledgments: This paper is dedicated to the memory of Carol-Ann Tetrault-Sirsly, a dearly missed friend and exceptional colleague with whom the first ideas underlying this research were conceived. We also wish to dedicate this paper to her loving family, and in particular, her husband Tony, and daughters Dominique and Francesca.

Conflicts of Interest: The authors declare no conflict of interest.

\section{References}

1. 10 Biggest Corporations Make More Money than Most Countries in the World Combined. Available online: https://www.globaljustice.org.uk/news/2016/sep/12/10-biggest-corporations-make-more-moneymost-countries-world-combined (accessed on 19 September 2019).

2. Rosanvallon, P. Democracy Past and Future; Moyn, S., Ed.; Columbia University Press: New York, NY, USA, 2007.

3. Amnesty International. Injustice Incorporated: Corporate Abuses and the Human Right to Remedy; Amnesty International: London, UK, 2014; Available online: https://www.amnesty.org/en/documents/POL30/001/2014/ en/ (accessed on 19 September 2019).

4. Imai, S.; Gardner, L.; Weinberger, S. The "Canada Brand": Violence and Canadian Mining Companies in Latin America; SSRN Scholarly Paper ID 2886584; Social Science Research Network: Rochester, NY, USA, 2017.

5. Kashyap, A. When Clothing Labels Are a Matter of Life or Death. Available online: https://www.hrw.org/ news/2018/05/02/when-clothing-labels-are-matter-life-or-death (accessed on 19 September 2019).

6. Donia, M.B.L.; Tetrault Sirsly, C.-A.; Ronen, S. Employee Attributions of Corporate Social Responsibility as Substantive or Symbolic: Validation of a Measure. Appl. Psychol. 2017, 66, 103-142. [CrossRef]

7. Glavas, A. Corporate Social Responsibility and Employee Engagement: Enabling Employees to Employ More of Their Whole Selves at Work. Front. Psychol. 2016, 7, 796. [CrossRef] [PubMed]

8. Farooq, O.; Payaud, M.; Merunka, D.; Valette-Florence, P. The Impact of Corporate Social Responsibility on Organizational Commitment: Exploring Multiple Mediation Mechanisms. J. Bus. Ethics 2014, 125, 563-580. [CrossRef]

9. Hansen, S.D.; Dunford, B.B.; Boss, A.D.; Boss, R.W.; Angermeier, I. Corporate Social Responsibility and the Benefits of Employee Trust: A Cross-Disciplinary Perspective. J. Bus. Ethics 2011, 102, 29-45. [CrossRef]

10. Donia, M.; Ronen, S.; Tetrault Sirsly, C.-A.; Bonaccio, S. CSR by Any Other Name? The Differential Impact of Substantive and Symbolic CSR Attributions on Employee Outcomes. J. Bus. Ethics 2019, 157. [CrossRef]

11. Aguinis, H. Organizational Responsibility: Doing Good and Doing Well. In APA Handbook of Industrial and Organizational Psychology, Vol 3: Maintaining, Expanding, and Contracting the Organization; Zedeck, S., Ed.; American Psychological Association: Washington, DC, USA, 2011; pp. 855-879. [CrossRef]

12. Carroll, A.B. Corporate Social Responsibility: Evolution of a Definitional Construct. Bus. Soc. 1999, 38, 268-295. [CrossRef] 
13. Economy, P. The (Millennial) Workplace of the Future Is Almost Here-These 3 Things Are About to Change Big Time. Available online: https://www.inc.com/peter-economy/the-millennial-workplace-of-future-isalmost-here-these-3-things-are-about-to-change-big-time.html (accessed on 19 September 2019).

14. Feldmann, D.; Hosea, J.; Ponce, J.; Wall, M.; Banker, L. Cause, Influence, and the Next Generation Workforce: The 2015 Millennial Impact Report. Available online: http://www.themillennialimpact.com/sites/default/ files/reports/2015-MillennialImpactReport_01_0.pdf (accessed on 25 September 2019).

15. Ruggie, J.G.; Middleton, E.K. Money, Millennials and Human Rights: Sustaining 'Sustainable Investing'. Glob. Policy 2019, 10, 144-150. [CrossRef]

16. Brammer, S.; Millington, A.; Rayton, B. The Contribution of Corporate Social Responsibility to Organizational Commitment. Int. J. Hum. Resour. Manag. 2007, 18, 1701-1719. [CrossRef]

17. Chun, J.S.; Shin, Y.; Choi, J.N.; Kim, M.S. How Does Corporate Ethics Contribute to Firm Financial Performance? The Mediating Role of Collective Organizational Commitment and Organizational Citizenship Behavior. J. Manag. 2013, 39, 853-877. [CrossRef]

18. Simons, P. International Law's Invisible Hand and the Future of Corporate Accountability for Violations of Human Rights. J. Hum. Rights Environ. 2011, 3, 5-43. [CrossRef]

19. Ruggie, J. Just Business: Multinational Corporations and Human Rights, 1st ed.; WW Norton: New York, NY, USA, 2013.

20. Deva, S.; Bilchitz, D. (Eds.) Human Rights Obligations of Business: Beyond the Corporate Responsibility to Respect? Cambridge University Press: Cambridge, UK, 2013. [CrossRef]

21. OECD. OECD Due Diligence Guidance for Responsible Business Conduct. Available online: https: //mneguidelines.oecd.org/OECD-Due-Diligence-Guidance-for-Responsible-Business-Conduct.pdf (accessed on 24 February 2020).

22. OECD. OECD Guidelines for Multinational Enterprises, 2011 Edition; OECD: Paris, France, 2011. [CrossRef]

23. Seck, S.L. Business, Human Rights, and Canadian Mining Lawyers. Can. Bus. L. J. 2015, 56, 30.

24. Simons, P.; Macklin, A. The Governance Gap: Extractive Industries, Human Rights, and the Home State Advantage, 1st ed.; Routledge: London, UK; New York, NY, USA, 2014.

25. Seck, S.; MacMaster, K. Devoir de Vigilance: A Canadian Perspective. Available online: https://www.researchgate. net/publication/331498166_Devoir_de_vigilance_a_canadian_perspective (accessed on 24 February 2019).

26. McCorquodale, R.; Smit, L.; Neely, S.; Brooks, R. Human Rights Due Diligence in Law and Practice: Good Practices and Challenges for Business Enterprises. Bus. Hum. Rights J. 2017, 2, 195-224. [CrossRef]

27. Glavas, A. Corporate Social Responsibility and Organizational Psychology: An Integrative Review. Front. Psychol. 2016, 7, 144. [CrossRef] [PubMed]

28. Greenberg, J.L.; Solomon, S.; Pyszczynski, T. Terror Management Theory of Self-Esteem and Cultural Worldviews: Empirical Assessments and Conceptual Refinements. Adv. Exp. Soc. Psychol. 1997, 29, 61-139. [CrossRef]

29. Aguinis, H.; Glavas, A. On Corporate Social Responsibility, Sensemaking, and the Search for Meaningfulness through Work. J. Manag. 2019, 45, 1057-1086. [CrossRef]

30. Fry, R. Millennials Are Largest Generation in the U.S. Labor Force; Pew Research Center: Washington, DC, USA, 2018.

31. Moldavskiy, V. Corporate Social Responsibility Can Be Good for Business. Available online: https://www.chicagotribune.com/business/success/tca-corporate-social-responsibility-good-forbusiness-20160531-story.html (accessed on 24 February 2020).

32. Meister, J. The Future of Work: Corporate Social Responsibility Attracts Top Talent. Available online: https:/www.forbes.com/sites/jeannemeister/2012/06/07/the-future-of-work-corporatesocial-responsiblity-attracts-top-talent/ (accessed on 24 February 2020).

33. Deloitte Global Millennial Survey 2016. Available online: https://www2.deloitte.com/global/en/pages/aboutdeloitte/articles/millennialsurvey.html (accessed on 24 February 2020).

34. Skarlicki, D.P.; Kulik, C.T. Third-Party Reactions to Employee (Mis)Treatment: A Justice Perspective. In Research in Organizational Behavior: An Annual Series of Analytical Essays and Critical Reviews, Volume 26; Elsevier Science/JAI Press: Amsterdam, The Netherlands, 2005; pp. 183-229.

35. Van Buren, H., III; Greenwood, M.; Sheehan, C. Strategic Human Resource Management and the Decline of Employee Focus. Hum. Resour. Manag. Rev. 2011, 21, 209-219. [CrossRef] 
36. Maignan, I.; Ferrell, O. Measuring Corporate Citizenship in Two Countries: The Case of the United States and France. J. Bus. Ethics 2000, 23, 283-297. [CrossRef]

37. Glavas, A.; Kelley, K. The Effects of Perceived Corporate Social Responsibility on Employee Attitudes. Bus. Ethics Q. 2014, 24, 165-202. [CrossRef]

38. Greening, D.W.; Turban, D.B. Corporate Social Performance as a Competitive Advantage in Attracting a Quality Workforce. Bus. Soc. 2000, 39, 254-280. [CrossRef]

39. Kim, S.-Y.; Park, H. Corporate Social Responsibility as an Organizational Attractiveness for Prospective Public Relations Practitioners. J. Bus. Ethics 2011, 103, 639-653. [CrossRef]

40. Stites, J.P.; Michael, J.H. Organizational Commitment in Manufacturing Employees: Relationships with Corporate Social Performance. Bus. Soc. 2011, 50, 50-70. [CrossRef]

41. Jones, D.A. Does Serving the Community Also Serve the Company? Using Organizational Identification and Social Exchange Theories to Understand Employee Responses to a Volunteerism Programme. J. Occup. Organ. Psychol. 2010, 83, 857-878. [CrossRef]

42. Sheel, R.C.; Vohra, N. Relationship between Perceptions of Corporate Social Responsibility and Organizational Cynicism: The Role of Employee Volunteering. Int. J. Hum. Resour. Manag. 2016, 27, 1373-1392. [CrossRef]

43. Carmeli, A.; Gilat, G.; Waldman, D. The Role of Perceived Organizational Performance in Organizational Identification, Adjustment and Job Performance. J. Manag. Stud. 2007, 44, 972-992. [CrossRef]

44. TetraultSirsly, C.-A.; Lvina, E. From Doing Good to Looking Even Better: The Dynamics of CSR and Reputation. Bus. Soc. 2019, 58, 1234-1266. [CrossRef]

45. McShane, L.; Cunningham, P. To Thine Own Self Be True? Employees' Judgments of the Authenticity of Their Organization's Corporate Social Responsibility Program. J. Bus. Ethics 2012, 108, 81-100. [CrossRef]

46. The Corporate Responsibility to Respect Human Rights-An Interpretive Guide. Available online: https: //www.ohchr.org/Documents/Publications/HR.PUB.12.2_En.pdf (accessed on 24 February 2020).

47. Abramovitch, S. Read a Disgruntled Whole Foods Employee's Epic Resignation Letter. Available online: https://gawker.com/5824287/read-a-disgruntled-whole-foods-employees-epic-resignation-letter (accessed on 24 February 2020).

48. Evans, W.R.; Goodman, J.M.; Davis, W.D. The Impact of Perceived Corporate Citizenship on Organizational Cynicism, OCB, and Employee Deviance. Hum. Perform. 2011, 24, 79-97. [CrossRef]

49. Working Group on Human Rights and Transnational Corporations and Other Business Enterprises. Available online: https://www.ohchr.org/EN/Issues/Business/Pages/ WGHRandtransnationalcorporationsandotherbusiness.aspx (accessed on 24 February 2020). 